\title{
PENGARUH SUHU PENGOLAHAN DENGAN METODE STEAM JACKET SEDERHANA TERHADAP KUALITAS MINYAK HATI IKAN PARI MONDOL
}

\section{The Effect of Processing Temperature of Simple Steam Jacket on The Quality of White Spotted Whipray Rays Liver Oil}

\author{
Wahyu Nur Widiyanto*, Ratna Ibrahim, Apri Dwi Anggo \\ Program Studi Teknologi Hasil Perikanan Jurusan Perikanan Fakultas Perikanan dan Ilmu Kelautan \\ Universitas Diponegoro, Jalan Prof. Soedarto, SH. Kampus UNDIP Tembalang, Semarang 50275. \\ Telepon/Faks: (024)7474698. \\ *Korespondensi: widiewayan@gmail.com \\ Diterima 19 Januari 2015/ Disetujui 10 April 2015
}

\begin{abstract}
Abstrak
Proses pengolahan di beberapa perusahaan minyak hati ikan dengan sistem steam jacket masih menggunakan suhu yang tinggi menghasilkan produk minyak yang mutunya kurang baik. Data tentang kualitas produk minyak hati ikan pari yang diolah secara steam jacket sederhana pada suhu $\leq 80^{\circ} \mathrm{C}$ belum diperoleh. Penelitian bertujuan menentukan suhu pengolahan minyak hati ikan metode steam jacket sederhana terhadap kualitas minyak hati ikan pari yang dihasilkan. Hasil penelitian menunjukkan bahwa makin rendah suhu pengolahan hati ikan pari mondol maka makin rendah pula nilai asam lemak bebas, bilangan peroksida dan rendemen, tetapi tidak memberikan pengaruh nyata terhadap kadar air dan organoleptik kecuali kekeruhan. Suhu pengolahan minyak hati ikan pari yang baik adalah $60^{\circ} \mathrm{C}$ selama 20 menit dengan karakteristik asam lemak bebas 0,68\%, bilangan peroksida 0,57 meq/kg, kadar air $0 \%$, rendemen 37,88\%, nilai organolepetik 7,97 $\leq \mu \leq 8,35$. Omega-3: 23,44\% dan omega-6: 10,19\%.
\end{abstract}

Kata kunci: Minyak hati ikan, steam jacket sederhana, suhu

\begin{abstract}
The application of high temperature steam jacket system in the industrial fish liver processing makes the product is of poor quality. The quality data of Rays liver oil processed by simple jacket steam with temperature above $80^{\circ} \mathrm{C}$ are currently not available. This research aimed to determine temperature of simple steam jacket processing method to the quality of White Spotted Whipray Rays liver oil. The differences of processing temperatures affected significantly the value of free fatty acid, peroxide, and yield; but did not affected significantly on the water content and the organoleptic value specification products except on turbidity. The most optimum processing temperature of Rays liver oil was at $60{ }^{\circ} \mathrm{C}$ for 20 minutes with the content of free fatty acids $0.68 \%$, the peroxide $0,57 \mathrm{meq} / \mathrm{kg}$, and the moisture of the oil $0 \%$. The product had yield $37.88 \%$, the sensory value $7.97 \leq \mu \leq 8.35$ and omega-3: $23.44 \%$, as well as omega-6: $10.19 \%$.
\end{abstract}

Keywords: Fish liver oil, simple steam jacket, temperature

\section{PENDAHULUAN}

Minyak ikan adalah salah satu zat gizi yang mengandung asam lemak kaya manfaat karena mengandung sekitar 25\% asam lemak jenuh dan $75 \%$ asam lemak tak jenuh. Asam lemak tak jenuh ganda atau Polyunsaturated
Fatty Acid (PUFA), diantaranya DHA. Kandungan minyak di dalam ikan ditentukan beberapa faktor, yaitu jenis ikan, jenis kelamin, umur (tingkat kematangan), musim, siklus bertelur, letak geografis perairan dan jenis makanan yang dikonsumsi ikan tersebut (Panagan et al. 2011). 
Mutu minyak ikan dipengaruhi oleh beberapa faktor antara lain bahan baku, penanganan pada saat proses produksi, suhu yang digunakan pada proses pembuatan, tekanan, kandungan partikel pada minyak ikan (Rossell 2009). Lama waktu pemasakan juga memberikan hasil kualitas minyak yang berbeda dalam pembuatan minyak ikan (Hadipranoto 2005).

Jenis pengolahan minyak ikan yang umum dilakukan yaitu pengolahan secara basah (wet rendering method) dan pengolahan secara kering (dry rendering method). Wet rendering method adalah proses pengolahan dengan penambahan sejumlah air selama berlangsungnya proses pengolahan tersebut. Dry rendering method adalah cara pengolahan tanpa penambahan air selama proses pengolahan berlangsung (Estiasih 2009).

Sistem steam jacket menyebabkan, uap beredar melingkari ruang antara jacket dan vessel (bejana) sehingga panas ditransfer secara tidak langsung melalui permukaan padat yang memisahkan bahan yang akan dipanaskan dari media pemanas. Jenis yang paling banyak digunakan pada steam jacket hanya terdiri dari sebuah silinder luar sekitar bejana (vessel). Uap beredar diluar jaket dan mengembun di dinding bejana (vessel). Bejana jaket juga dapat berisi ruang udara internal sekitar jaket, hal ini untuk memastikan bahwa uap sesedikit mungkin mengembun di dinding luar jaket, dan bahwa panas tersebut dipindahkan ke dalam bejana (Lee et al. 2014).

Hati ikan pari sebagai sumber minyak berkualitas tinggi yang cocok untuk dikonsumsi manusia. Beberapa peneliti telah mengungkapkan tingginya proporsi minyak dalam hati ikan pari (Sellami et al. 2014). Penelitian Pascal et al. (2007), hati ikan pari (Himantura bleekeri) kaya akan lemak (54\% dari bahan baku). Kandungan asam lemak tak jenuh ganda dari minyak hati ikan pari EPA dan DHA yang tinggi masing masing 4\% dan 16\%. Penelitian Ould El Kebir et al. (2007), melaporkan bahwa hati dari tiga spesies ikan pari yang ditangkap di Republik Mauritania memiliki konsentrasi EPA dan DHA berkisar 1,88-5,01\% dan 10,00-13,04\%.

Penelitian ini bertujuan menentukan suhu pengolahan dengan metode steam jacket sederhana selama 20 menit terhadap karakteristik minyak hati ikan pari mondol (Himantura gerrardi).

\section{BAHAN DAN METODE}

\section{Bahan dan Alat}

Bahan yang digunakan adalah hati ikan pari mondol (Himantura gerrardi) segar yang diperoleh dari limbah pengolahan ikan asap di daerah Bandarharjo Semarang, Jawa Tengah. Berat ikan berkisar antara $2-3 \mathrm{~kg}$. berat hati sekitar $70 \mathrm{~g}$ per ekor. Hati ikan pari ditempatkan dalam box styerofoam yang diberi serpihan es dengan perbandingan 2:1 untuk menjaga kualitas hati ikan pari. Bahan lain diantaranya kloroform, larutan KI (Merck), $\mathrm{Na}_{2} \mathrm{~S}_{2} \mathrm{O}_{3}$ (Merck), asam asetat, larutan amilum, aquadest (Bratachem), etanol (Bratachem), indikator PP (Merck), $\mathrm{NaOH}$ Tekhnis (Merck), sodium hidroksida (Merck). Alat yang diperlukan pada penelitian ini adalah steam jacket sederhana yang digunakan yaitu panci pengukus (panci luar) terbuat dari alumunium berukuran tinggi $25 \mathrm{~cm}$ dengan diameter 30 $\mathrm{cm}$, panci untuk wadah hati dan minyak ikan yang dihasilkan (panci dalam) terbuat dari stainless steel berukuran tinggi $10 \mathrm{~cm}$ dengan diameter $15 \mathrm{~cm}$ pada bagian tengah masingmasing penutup panci sudah diberi lubang sebesar diameter termometer pengukur suhu yang harus tercapai sesuai masing-masing perlakuan, Centrifuge (Gemmy PLC-03) dan GCMS-QP2010S (SHIMADZU).

\section{METODE PENELITIAN}

Percobaan dirancang dengan Rancangan Acak Kelompok (RAK) dengan perlakuan suhu pengolahan yang berbeda, yaitu $70^{\circ} \mathrm{C}$, $65^{\circ} \mathrm{C}$, dan $60^{\circ} \mathrm{C}$. Pemilihan suhu $70^{\circ} \mathrm{C}, 65^{\circ} \mathrm{C}$, dan $60^{\circ} \mathrm{C}$ dengan lama pengolahan 20 menit didasarkan pada penelitian pendahuluan. 
Nunez (2007) menyatakan bahwa suhu pengolahan minyak hati ikan tidak boleh lebih dari $80^{\circ} \mathrm{C}$.

Masing-masing perlakuan diulang tiga kali. Variabel mutu produk yang diamati adalah asam lemak bebas, bilangan peroksida, kadar air, rendemen, organoleptik, serta uji pendukung profil asam lemak untuk produk yang terbaik.

Prosedur pembuatan minyak hati ikan pari mengacu pada prosedur yang digunakan oleh Bimbo (2011) yaitu sebagai berikut: hati ikan pari dicuci dengan air bersih selanjutnya dipotong potong berukuran sekitar $3 \mathrm{~cm}$ kemudian dilumatkan menggunakan blender. Panci pengukus (panci luar) diisi dengan air sebanyak 1 liter sampel (300 g) dimasukkan ke dalam panci dalam. Panci dalam dan panci luar ditutup dengan masing masing penutup panci. Panci tersebut kemudian dipanaskan dengan kompor gas hingga masing masing perlakuan mencapai suhu uap air sesuai dengan perlakuan $70^{\circ} \mathrm{C}, 65^{\circ} \mathrm{C}$, $60^{\circ} \mathrm{C}$ dan ditunggu selama 20 menit. Minyak yang terbentuk dipisahkan dengan cara diendapkan. Endapan terdiri dari tiga lapisan yaitu padatan, air dan minyak. Padatan yang masih mengandung minyak dipisahkan menggunakan alat centrifuge pada kecepatan 4000 rpm selama 20 menit.

Metode pengujian secara kuantitatif yaitu nilai asam lemak bebas berdasarkan prosedur dari SNI 01-2901-2006 (BSN 2006), bilangan peroksida berdasarkan prosedur dari (AOAC 1995), kadar air berdasarkan prosedur dari (AOAC 2007), rendemen berdasarkan prosedur dari (Immanuel 2010), sedangkan metode pengujian secara kualitatif yaitu profil asam lemak berdasarkan prosedur dari (AOAC 2007), dan organoleptik minyak hati ikan berdasarkan prosedur dari SNI 2730.1:2013 (BSN 2013). Data dianalisis menggunakan ANOVA dan perbedaan diantara perlakuan diuji dengan Uji Beda Nyata Jujur (BNT).

\section{HASIL DAN PEMBAHASAN Asam Lemak Bebas}

Kadar asam lemak bebas terendah terdapat pada pengolahan dengan suhu $60^{\circ} \mathrm{C}(0,68 \%)$ (Tabel 1). Semakin tinggi suhu pengolahan pada minyak hati ikan menyebabkan semakin tinggi pula kadar asam lemak bebas yang didapatkan sehingga bisa mempengaruhi kualitas minyak ikan. Paul dan Mittal (1997) menyatakan bahwa asam lemak bebas disebabkan oleh hidrolisis dan oksidasi minyak disebabkan oleh radikal bebas dan dekomposisi ikatan ganda selama pemanasan. Indikasi tingkat hidrolisis yang terjadi pada minyak dapat ditentukan dengan nilai asam lemak bebas.

Kadar asam lemak bebas hasil penelitian hampir sama dengan hasil penelitian lainnya. Penelitian yang dilakukan oleh Navarro et al. (2010) tentang stabilitas penyimpanan minyak hati pada dua spesies ikan pari dari teluk Mexico yang diekstrak dengan metode pengukusan pada suhu $45^{\circ} \mathrm{C}$ selama 1 jam menghasilkan minyak hati ikan dengan kadar asam lemak bebas minyak hati ikan pari $R$. bonasus sebesar 1,4\%; sedangkan

Tabel 1 Nilai rerata asam lemak bebas, bilangan peroksida, kadar air, dan rendemen minyak hati ikan pari mondol dengan perbedaan suhu pengolahan menggunakan metode steam jacket sederhana

\begin{tabular}{lcccc}
\hline Suuhu pengolahan & $\begin{array}{c}\text { Asam lemak } \\
\text { bebas }\end{array}$ & $\begin{array}{c}\text { Bilangan peroksida } \\
(\mathrm{meq} / \mathrm{kg})\end{array}$ & Kadar air & $\begin{array}{c}\text { Rendemen } \\
(\%)\end{array}$ \\
\hline $60^{\circ} \mathrm{C}$ & $0,68 \pm 0,07^{\mathrm{a}}$ & $0,57 \pm 0,19^{\mathrm{a}}$ & $0,00 \pm 0,00^{\mathrm{a}}$ & $36,88 \pm 1,70^{\mathrm{a}}$ \\
$65^{\circ} \mathrm{C}$ & $0,83 \pm 0,02^{\mathrm{b}}$ & $1,99 \pm 0,12^{\mathrm{b}}$ & $0,00 \pm 0,00^{\mathrm{a}}$ & $42,78 \pm 1,17^{\mathrm{b}}$ \\
$70^{\circ} \mathrm{C}$ & $0,98 \pm 0,02^{\mathrm{c}}$ & $4,03 \pm 0,68^{\mathrm{c}}$ & $0,00 \pm 0,00^{\mathrm{a}}$ & $50,44 \pm 1,01^{\mathrm{c}}$ \\
\hline Keteran $^{\mathrm{c}}$ & & &
\end{tabular}


minyak hati ikan pari $A$. narinari $0,64 \%$. Persyaratan mutu kadar asam lemak bebas minyak hati ikan menurut BSN No.2730-12013 adalah maksimal 1,5\%.

\section{Bilangan Peroksida}

Bilangan peroksida mengalami kenaikan sebesar 2 kali lipat terjadi pada suhu pengolahan minyak hati ikan pari $65^{\circ} \mathrm{C}$ ke $70^{\circ} \mathrm{C}$ (Tabel 1). Semakin tinggi suhu pengolahan pada minyak hati ikan pari maka semakin tinggi pula bilangan peroksida produk. Penggunaan suhu yang tinggi selama proses pengolahan minyak hati ikan dapat memicu laju kecepatan oksidasi. Perbedaan suhu $5^{\circ} \mathrm{C}$ antara suhu $60^{\circ} \mathrm{C}$ dan $65^{\circ} \mathrm{C}$ menyebabkan bilangan peroksida naik $150-200 \%$, sedangkan perbedaan suhu $10^{\circ} \mathrm{C}$ antara suhu $60^{\circ} \mathrm{C}$ dan $70^{\circ} \mathrm{C}$ naik hingga $350 \%$. Tehrany et al. (2012) menyatakan bahwa ketika minyak ikan mengalami oksidasi akan menghasilkan senyawa yang tidak stabil seperti radikal bebas dan hidroperoksida yang rentan terhadap dekomposisi lebih lanjut menjadi produk seperti aldehid dan keton. Kecepatan oksidasi lemak akan bertambah dengan kenaikan suhu dan berkurang pada suhu rendah.

Pengolahan minyak hati ikan pari mondol dengan metode steam jacket sederhana menghasilkan bilangan peroksida yang rendah jika dibandingkan dengan penelitian yang dilakukan oleh Jayasinghe et al. (2000) menyatakan tentang pengaruh metode ekstraksi terhadap kualitas minyak hati ikan Hiu (Charcarinus falciformis). Metode wet rendering (penambahan air 20\% dipanaskan suhu $80^{\circ} \mathrm{C}$ selama 30 menit) menghasilkan bilangan peroksida $9,1 \mathrm{meq} / \mathrm{kg}$.

\section{Kadar Air}

Tabel 1 menunjukkan bahwa dari ketiga perlakuan nilai kadar airnya bernilai $0 \%$. Kadar air yang rendah pada minyak hati ikan pari disebabkan proses pengolahan minyak hati ikan dengan steam jacket sederhana tidak ditambah air secara langsung, tetapi tambahan airnya hanya berasal dari uap air panas yang menyebabkan jumlah airnya sedikit, selain itu pada tahapan sentrifugasi dengan kecepatan yang tinggi yaitu $4000 \mathrm{rpm}$ selama 20 menit sehingga airnya relatif sedikit.

Kadar air minyak hati ikan pari hasil penelitian memenuhi standar kadar air minyak hati ikan secara nasional maupun internasional. Menurut Badan Standardisasi Nasional (2013), persyaratan mutu minyak hati ikan cucut botol mentah kadar air maksimal 0,3\%. Standar kadar air minyak hati ikan yang baik adalah <1\% (Gupta 2012).

\section{Rendemen}

Tabel 1 menunjukkan bahwa kenaikan suhu $5^{\circ} \mathrm{C}$ menyebabkan kenaikan rendemen berkisar antara 20\% sampai dengan $40 \%$, sedangkan perbedaan suhu $10^{\circ} \mathrm{C}$ menyebabkan kenaikan rendemen berkisar $40 \%$. Semakin tinggi suhu pemanasan maka semakin banyak protein yang rusak karena proses denaturasi, mengakibatkan semakin banyak pula minyak yang dihasilkan. Benjakul (2000) menyatakan bahwa suhu yang lebih rendah memberikan hasil rendemen yang lebih rendah. Pemasakan dapat menggumpalkan protein yang terdapat pada ikan sehingga sel sel jaringan berlemak akan terganggu melepaskan minyak ke fase cair oleh karena itu pemisahan padatan dan minyak harus secara mekanis.

Kadar rendemen minyak hati ikan pari mondol hasil penelitian berada pada kisaran kadar rendemen minyak hati ikan beberapa penelitian. Penelitian yang dilakukan oleh Immanuel dan Palavesam (2010), tentang sifat fisika kimia dan profil asam lemak minyak hati Red-toothed Triggerfish (Odonus niger) menggunakan ekstraksi steam jacket sebesar $42,58 \%$. Penelitian yang dilakukan oleh Navarro et al. (2004) tentang karakteristik fisika kimia minyak hati ikan pari dari teluk Meksiko dengan metode ekstraksi pengukusan suhu $45^{\circ} \mathrm{C}$ selama 1 jam menghasilkan rendemen minyak hati ikan pari spesies R. bonasus 43\%, A. narinari $41,2 \%$, dan $D$. americana $38,2 \%$. 
Tabel 2 Nilai selang kepercayaan minyak hati ikan pari mondol dengan perbedaan suhu pengolahan metode steam jacket sederhana

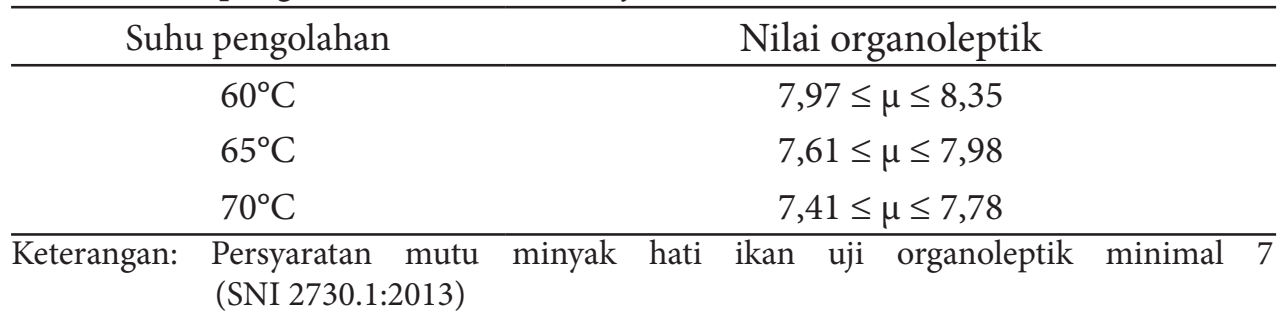

Hasil penelitian menunjukkan bahwa pengolahan hati ikan pari dengan suhu dibawah $70^{\circ} \mathrm{C}$ dengan metode steam jacket dan pemisahan minyak dengan alat sentrifuge menghasilkan rendemen sekitar 30-40\%.

\section{Organoleptik Minyak Hati Ikan Pari}

Hasil uji organoleptik (Tabel 2) menunjukkan bahwa nilai produk pada ketiga macam suhu pengolahan memenuhi persyaratan nilai mutu minyak ikan menurut SNI.

\section{Kekeruhan}

Hasil uji lanjut data perlakuan perbedaan suhu pengolahan menujukkan bahwa produk yang diolah dengan suhu $60^{\circ} \mathrm{C}$ lebih jernih dibandingkan dengan produk yang diolah pada suhu $65^{\circ} \mathrm{C}$ dan $70^{\circ} \mathrm{C}$ yang warnanya lebih keruh. Boran et al. (2006) menyatakan bahwa perubahan kejernihan minyak dapat dipengaruhi oleh adanya produk-produk degradasi minyak maupun sisa-sisa bahan yang tertinggal di dalam minyak. Penurunan kejernihan minyak juga dapat disebabkan oleh oksidasi pigmen (pigmen sintetik dan pigmen alami, dalam hal ini $\beta$ karoten) yang terdapat di dalam minyak.

\section{Warna}

Hasil data uji warna (Tabel 3) menunjukkan bahwa tidak terdapat perbedaan warna produk diantara ketiga perlakuan. Minyak hati ikan pari mondol hasil penelitian rata-rata berwarna kuning emas sampai kuning kemerahan. Warna tersebut berasal dari pigmen karotenoid yang terdapat dalam hati ikan Pari. Pengolahan dengan menggunakan suhu tinggi dapat menyebabkan perubahan warna pada produk minyak hati ikan karena terjadi reaksi oksidasi yang menimbulkan warna minyak menjadi cokelat dan pigmen karotenoid memudar. Navaro et al. (2009) menyatakan bahwa karotenoid dan tokoferol merupakan antioksidan alami yang paling efektif dalam melindungi minyak dari oksidasi. Ikan pari tidak mampu mensintesis karotenoid, tetapi mendapatkannya dari krustasea atau plankton sebagai makanan mereka. Karotenoid secara alami terdapat dalam hati dan diekstraksi menjadi minyak.

Tabel 3 Nilai rerata uji organoleptik minyak hati ikan pari mondol dengan perbedaan suhu pengolahan menggunakan metode steam jacket sederhana

\begin{tabular}{lccr}
\hline \multirow{2}{*}{ Spesifikasi } & $60^{\circ} \mathrm{C}$ & $65^{\circ} \mathrm{C}$ & $70^{\circ} \mathrm{C}$ \\
\cline { 2 - 4 } & $8,93 \pm 0,37^{\mathrm{a}}$ & $7,73 \pm 1,11^{\mathrm{b}}$ & $7,4 \pm 1,22^{\mathrm{b}}$ \\
\hline Kekeruhan & $6,73 \pm 0,87^{\mathrm{a}}$ & $6,8 \pm 1,10^{\mathrm{a}}$ & $6,53 \pm 1,01^{\mathrm{a}}$ \\
Warna & $8,8 \pm 0,81^{\mathrm{a}}$ & $8,87 \pm 0,51^{\mathrm{a}}$ & $8,87 \pm 0,51^{\mathrm{a}}$ \\
Bau & \multicolumn{3}{c}{ Suhu pengolahan } \\
Keterangan: & Huruf superscript yang berbeda pada kolom & yang sama \\
& menunjukkan adanya perbedaan nyata $(p<0,05)$. &
\end{tabular}




\section{Bau}

Nilai bau pada hasil penelitian pembuatan minyak hati ikan pari mondol menunjukkan hasil yang tidak berbeda nyata. Nilai ratarata bau yang didapatkan dari hasil penelitian adalah 8,8 (Tabel 3). Minyak hati ikan pari mondol yang dihasilkan menghasilkan bau/ aroma yang khas spesifik jenis minyak ikan. Minyak hati ikan berbau amis. Menurut Gupta et al. (2013), minyak hati ikan yang berkualitas baik memiliki karakteristik bau yang amis spesifik jenis ikan tetapi tidak berbau tengik.

\section{Profil Asam Lemak Minyak Hati Ikan Pari}

Profil asam lemak minyak hati ikan pari mondol yang diolah pada suhu $60^{\circ} \mathrm{C}$ mengandung asam lemak jenuh(saturated fatty acid $=$ SFA), asam lemak tak jenuh tunggal ( monounsaturated fatty acid $=$ MFA), dan asam lemak tak jenuh jamak (Polyunsaturated Fatty Acid $=$ PUFA). Profil asam lemak minyak hati ikan pari mondol tersaji pada Tabel 4.

Profil asam lemak dari minyak hati ikan pari mondol menunjukkan hasil bahwa asam lemak yang mendominasi adalah golongan asam lemak jenuh yaitu asam palmitat $33,01 \%$ dari total SFA 35,33\%. Hasil asam palmitat minyak hati ikan pari mondol lebih tinggi dari penelitian yang dilakukan oleh Pascal et al. (2007) tentang komposisi asam lemak dari minyak hati ikan pari (Himantura bleekeri) menggunakan metode ekstraksi sokhlet diperoleh hasil asam palmitat (C16:0) sejumlah 28,33\%.
Kandungan asam lemak omega 3 dan omega 6 pada minyak hati ikan pari hasil penelitian secara berturut turut adalah 23,44 $\%$ dan 10, 19\%. Hasil asam lemak omega 3 dan omega 6 nilainya agak berbeda dengan hasil penelitian minyak hati ikan pari yang dilakukan oleh Pascal et al. (2007) tentang komposisi asam lemak dari minyak hati ikan pari (Himantura bleekeri) mengandung omega 3 dan omega 6 sejumlah 27,09\% dan 4,06\%. Rasyid (2000) menyatakan bahwa asam lemak Omega-3 yaitu asam lemak yang posisi ikatan rangkap pertamanya terletak pada atom karbon nomor tiga dari ujung gugus metilnya. Asam asam lemak alami yang termasuk dalam kelompok asam lemak omega 3 adalah linoleat, eikosapentaenoat, dan dokosaheksaenoat.

Perbedaan metode ekstraksi pada pembuatan minyak hati ikan akan mempengaruhi jumlah komposisi asam lemak yang diperoleh terutama asam lemak omega 3 dan omega 6 yang sangat peka terhadap proses oksidasi. Khamidinal et al. (2007) menyatakan adanya perlakuan pemasakan dan penyimpanan ikan yang kurang tepat dapat menyebabkan perubahan-perubahan fisik maupun komposisi kimia. Perubahan kimiawi maka kemungkinan besar akan terdapat degradasi asam lemak omega-3. Pengaruh luar, misalnya suhu, radiasi, logam katalis dapat mempercepat laju oksidasi asam lemak tersebut, yang akibat lanjutannya, terjadi penurunan mutu zat gizi yang terkandung dalam bahan tersebut.

Tabel 4 Profil asam lemak minyak hati ikan pari mondol yang diola dengan metode steam jacket sederhana pada suhu $60^{\circ} \mathrm{C}$ selama 20 menit

\begin{tabular}{|c|c|c|}
\hline \multicolumn{2}{|c|}{ Jenis asam lemak } & Persentase area (\%) \\
\hline \multirow{3}{*}{ SFA } & Miristat & 1,86 \\
\hline & Palmitat & 33,01 \\
\hline & Stearat & 0,46 \\
\hline \multirow{2}{*}{ MUFA } & Oleat & 19,03 \\
\hline & Lignocerit & 5,81 \\
\hline \multirow{2}{*}{ PUFA } & Omega 3 & 23,44 \\
\hline & Omega 6 & 10,19 \\
\hline
\end{tabular}




\section{KESIMPULAN}

Produk yang terbaik dan memenuhi sebagian persyaratan mutu menurut SNI No. 2730-1-2013 dan Draft Codex serta mengandung omega-3 dan omega-6 yaitu produk yang diolah pada suhu $60^{\circ} \mathrm{C}$ selama 20 menit.

\section{DAFTAR PUSTAKA}

[AOAC] Association of Official Analytical Chemist. 1995. Official Methods of Analysis of The Association of Official Analytical Chemist. Arlington, Virginia (USA): Association of Official Analytical Chemists Inc.

[AOAC] Association of Official Analytical Chemist. 2007. Official Methods of Analysis of The Association of Official Analytical Chemist. Arlington, Virginia (USA): Association of Official Analytical Chemists Inc.

[BSN] Badan Standardisasi Nasional. 2006. Standar Nasional Indonesia No. 01-29012006. Prosedur Pengujian Asam Lemak Bebas. http://websisni.bsn.go.id (diakses tanggal 12 September 2014).

[BSN] Badan Standardisasi Nasional. 2013. Standar Nasional Indonesia No.27301-2013. Minyak hati Ikan Cucut Botol Mentah Bagian Spesifikasi. http:// websisni.bsn.go.id (diakses tanggal 12 September 2014).

Benjakul S, Chantachum S, Sriwirat N. 2000. Separation and quality of fish oil from precooked and non-precooked tuna heads. Journal Food Chemistry (69):289294.

Bimbo AP. 2011. Edible Oil Processing. The Production and Processing of Marine Oils: AOAC Lipid Library.

Boran G, Karacam H, Muhammet B. 2006. Changes in the quality of fish oils due to storage temperature and time. Journal Food Chemistry (98):693-698

Estiasih T. 2009. Minyak Ikan, Teknologi dan Penerapannya untuk Pangan dan Kesehatan: Graha Ilmu.
Gupta P, Singhal K, Jangra AK, Nautiyal V, Pandey A. 2012. Shark liver oil: a review. Asian Journal of Pharmaceutical Education and Research 1(2):1-15.

Hadipranoto N. 2005. Kajian stabilitas thermal EPA dan DHA dalam minyak ikan mujahir (Oreochromis sp.). Indonesian Journal of Chemistry 5(2):152-155.

Immanuel G, Palavesam A. 2010. Comparative study on the liver fatty acid profiles of the red toothed trigger fish (Odonus niger) from southwest coast of india. Irian Journal of Fisheries Sciences 9(1):97-110.

Jayasinghe CVL, Perera WMK, Bamunuarachchi A. 2000. Influence of extraction methods on quality of shark liver oils. Journal National Aquatic Resources Research 182-188.

Lee CM, Apostolidis E, Karayannakidis PD. 2014. comparison of direct steam injection and steam-jacketed heating in squid protein hydrolysis for energy consumption and hydrolysis performance. Journal Food Science and Technology (57): 134-140.

Khamidinal, Hadipranoto N, Mudasir. 2007. Pengaruh antioksidan terhadap kerusakan asam lemak omega 3 pada proses pengolahan ikan tongkol (Euthynus sp.). Jurnal Kaunia Gajah Mada 3(2):119-138.

Navarro Garci'a G, Aguilar PR, Alvarado BL, Garc1'a OJ. 2004ª Characterization of the lipid composition and natural antioxidants in the liver oil of Dasyatis brevis and Gymnura marmorata Rays. Journal Food Chemistry (87):89-96.

Navarro G, Suarez JCR, Garcia JU. 2009. Lipid composition, natural antioxidants and physicochemical characteristics in liver oil from rajiforms from the gulf of mexico. Journal American Oil Chemistry Society (86):323-328.

Navarro Garc1'a G, Ramirez Suarez JC, Alvarado BL, Quiñones CE, Farías MF. $2010^{c}$. Storage stability of liver oil from two ray (Rhinoptera bonasus and Aetobatus narinari) species from the gulf of mexico. 
Journal Food Chemistry (119):1578-1583. Nunez CG. 2007. Quality and stability of cuban shark liver oil: comparison with icelandic cod liver oil. Journal United Nation University. 4(2):1-38.

Ould El Kebir MV, Barnathan G, Gaydou EM, Siau I, Miralles J. 2007. Fatty acids in liver, muscle and gonad of three tropical rays including non-methylene-interrupted dienoic fatty acids. Journal American Oil Chemistry Society 42: 525-535.

Panagan AT, Yohandini H, Gultom JU. 2011. Analisis kualitatif dan kuantitatif asam lemak tak jenuh omega-3 dari minyak ikan patin (Pangasius pangasius) dengan metoda kromatografi gas. Jurnal Penelitian dan Sains 14(4).

Pascal BJ, Paul GJ, Dubois N, Le Néchet S. 2007. Lipid composition of the liver oil of the ray Himantura bleekeri. Journal Food Chemistry 104(2):559-564.

Paul S, Mittal G S. 1997. Regulating the use of degraded oil fat in deep-fat oil food frying. Journal Food Science Nutrient 37(7): 635-662.

Raharja S, Suryadarma P, Oktavia T. 2011. Hidrolisis enzimatik minyak ikan untuk produksi asam lemak omega-3 menggunakan lipase dari Aspergillus niger. Jurnal Teknologi dan Industri Pangan 22(1): 64-72.

Rasyid A. 2003. Asam lemak omega-3 dari minyak ikan. Jurnal Oseana 28(3): 11-16.

Rossell B. 2009. Fish oil. United Kingdom: Blackwell Publishing.

Sellami M, Rebah BF, Gargouri Y, Miled N. 2014. Lipid composition and antioxidant activity of liver oils from ray species living in Tunisian coasts. Arabian Journal of Chemistry 7(10):1-7.

Tehrany EA, Jacquot M, Gaiani C, Imran M, Desobry S, Linder M. 2012. Beneficial effect and oxidative stability of omega-3 long-chain Polyunsaturated Fatty Acids. Journal Food Science and Technology 25: 24-33. 